University of Nebraska - Lincoln

DigitalCommons@University of Nebraska - Lincoln

Faculty Publications: Department of

Entomology

Entomology, Department of

2001

\title{
Dispersal of Adult European Corn Borer (Lepidoptera: Crambidae) Within and Proximal to Irrigated and Non-irrigated Corn
}

Thomas E. Hunt

University of Nebraska-Lincoln, thunt2@unl.edu

Leon G. Higley

University of Nebraska-Lincoln, Ihigley1@unl.edu

John F. Witkowski

University of Nebraska-Lincoln, jwitkowski1@unl.edu

Linda J. Young

University of Nebraska-Lincoln, lyoung3@unl.edu

Richard L. Hellmich

USDA-ARS

Follow this and additional works at: https://digitalcommons.unl.edu/entomologyfacpub

Part of the Entomology Commons

Hunt, Thomas E.; Higley, Leon G.; Witkowski, John F.; Young, Linda J.; and Hellmich, Richard L., "Dispersal of Adult European Corn Borer (Lepidoptera: Crambidae) Within and Proximal to Irrigated and Non-irrigated Corn" (2001). Faculty Publications: Department of Entomology. 293.

https://digitalcommons.unl.edu/entomologyfacpub/293

This Article is brought to you for free and open access by the Entomology, Department of at DigitalCommons@University of Nebraska - Lincoln. It has been accepted for inclusion in Faculty Publications: Department of Entomology by an authorized administrator of DigitalCommons@University of Nebraska - Lincoln. 


\title{
Dispersal of Adult European Corn Borer (Lepidoptera: Crambidae) Within and Proximal to Irrigated and Non-irrigated Corn
}

\author{
THOMAS E. HUNT, ${ }^{1}$ LEON G. HIGLEY, ${ }^{2}$ JOHN F. WITKOWSKI, ${ }^{3}$ LINDA J. YOUNG, ${ }^{4}$ AND \\ RICHARD L. HELLMICH ${ }^{5}$
}

Department of Entomology, Haskell Agricultural Laboratory, University of Nebraska Northeast Research and Extension Center, 57905866 Road, Concord, NE 68728

\begin{abstract}
J. Econ. Entomol. 94(6): 1369-1377 (2001)
ABSTRACT The European corn borer, Ostrinia nubilalis (Hübner), causes economic damage to corn, Zea mays L., throughout the Corn Belt. Because this insect has become the primary target of Bacillus thuringiensis Berliner (Bt) transgenic corn, current efforts addressing the management of O. nubilalis resistance to Bt corn require information on adult European corn borer dispersal and factors affecting its dispersal. In 1998 we conducted mark-release-recapture, release-recapture, and caged-mating studies to directly measure and compare local dispersal patterns of $O$. nubilalis adults within and proximal to irrigated and non-irrigated cornfields. Releases of marked adults were made corresponding to the first and second flight of $O$. nubilalis in eastern Nebraska. Adult dispersal was significantly different between irrigated and non-irrigated cornfields. Released adults tended to remain in and near irrigated cornfields, but dispersed out of and away from non-irrigated cornfields. When released at the edge of the cornfield, neither male nor unmated female $O$. nubilalis displayed an initial tendency to move out of irrigated corn and into the mixed smooth bromegrass (Bromus inermis Leyss) and broadleaf-weed field edge. Mating efficiency in a late-season cornfield was not significantly different than in dense foxtail (Setaria spp.). Generally, we found that adult O. nubilalis dispersal may vary depending on variables such as action-site availability and agronomic practices and their interaction with $O$. nubilalis life history.
\end{abstract}

KEY WORDS Ostrinia nubilalis, resistance management, insect dispersal

MuCH WORK HAS been devoted to the biology and behavior of the European corn borer, Ostrinia nubilalis (Hübner), driven by the need to determine the effects of $O$. nubilalis injury to crops, particularly corn (Zea mays L.) to assess economic damage, and to develop management tactics. Ostrinia nubilalis has become the primary target of transgenic corn hybrids that contain a modified gene expressing an insecticidal protein from the bacterium Bacillus thuringiensis Berliner (Bt) (Koziel et al. 1993). Because of the strong selection pressure that the $\mathrm{Bt}$ corn hybrids exert on the insect, there is a concern that $O$. nubilalis resistance to Bt proteins could develop. Thus, O. nubilalis has become the focus of resistance management modeling.

Although considerable information exists on $O . n u$ bilalis biology, information required to fully understand $O$. nubilalis mating biology and to model the

This article reports the results of research only. Mention of a propriety product does not constitute an endorsement or recommendation for its use by USDA.

${ }^{1}$ E-mail: thunt2@unl.edu.

${ }^{2}$ Department of Entomology, 202 Plant Industry Building, University of Nebraska, Lincoln, NE 68583.

${ }^{3}$ Lifelong Learning Center, University of Nebraska NEREC, $601 \mathrm{E}$ Benjamin Avenue, Suite 104, Norfolk, NE 68701.

${ }^{4}$ Department of Biometry, 103 Miller Hall, University of Nebraska, Lincoln, NE 68583.

${ }^{5}$ USDA-ARS Corn Insects and Crop Genetics Research Unit, Genetics Building, c/o Insectary, Iowa State University, Ames, IA 50011. development of $O$. nubilalis resistance is lacking. A precise estimate of gene flow, which is in part a function of premating dispersal, is a key component to estimating the rate of resistance evolution. Reduced rate of gene flow (e.g., reduced premating dispersal) can increase the rate of resistance evolution (Tabashnik and Croft 1982, Caprio 1998). The need for precise answers to questions concerning gene flow has driven renewed interest in adult $O$. nubilalis dispersal and mating behavior.

Measures of moisture (particularly dew point and relative humidity) have been positively correlated to localized $O$. nubilalis population density, flight activity, and various physiological parameters. High adult O. nubilalis densities have been associated with damp ground and the presence of dew or free water (DeRozari et al. 1977). Drinking water is essential for egg production and fertility (Kira et al. 1969), and female longevity and body water content decline as relative humidity is reduced, even in the presence of free water (Vance 1949). Female calling activity begins earlier and lasts longer under high-humidity compared with low-humidity conditions (Webster and Cardé 1982, Royer and McNeil 1991), and mating success is increased (Sparks 1963, Royer and McNeil 1991). Flight activity also increases under high-humidity conditions (Showers et al. 1974). Although it is debatable which moisture parameters are the most 
appropriate correlates (parameters associated with free water or moisture content of the air) for adult $O$. nubilalis behavior, or how moisture parameters interact with other parameters, it is clear that moisture is vital for mating and oviposition.

Showers et al. (1976) proposed that most O. nubilalis mating activity occurs in grassy areas (action sites) within or outside of cornfields; these sites may be found $100 \mathrm{~m}$ from the nearest cornfield. Action sites harbored adults (Showers et al. 1976, DeRozari et al. 1977, Showers et al. 1980, Sappington and Showers 1983, Derrick and Showers 1990) and had a humid microclimate favorable (due to high relative humidity and early dew formation) for the adult $O$. nubilalis (Showers et al. 1974, DeRozari et al. 1977). Based on $O$. nubilalis response to microclimate, a general descriptive model of local adult $O$. nubilalis dispersal in Iowa emerged (Showers et al. 1980). After adult emergence, unmated females leave the cornfield (unless the field is weedy) and fly to nearby action sites to rest and mate, fly to another action site or cornfield to oviposit, fly back out of the corn to another (or the same) action site, and so on. Males, in contrast, leave the corn upon emergence and fly to an action site to mate. Males remain at the action site until females at that site have dispersed, at which time males move to other action sites.

Although the Showers et al. (1980) model describes general $O$. nubilalis dispersal in and around non-irrigated cornfields in Iowa, more specific dispersal information is required, particularly for irrigated cornfields. Most previous research, although providing much information on the factors affecting $O$. nubilalis behavior, did not directly examine dispersal. That is, the specific field of origin (corn or other plant) of the sampled adults could not be established. Also, research was conducted in and around non-irrigated cornfields. Perhaps irrigated corn provides a humid microclimate favorable for adult O. nubilalis. Besides the regular application of water, planting density is generally greater in irrigated fields. Irrigation facilitates in a dense canopy that is protective, reducing light penetration and air movement. In regions where few natural action sites exist near cornfields (e.g., southeastern Alberta, Canada), O. nubilalis adults are reported to remain in corn (Lee 1988).

In 1996 we began a series of studies in eastern Nebraska that examined adult $O$. nubilalis local dispersal and mating behavior (Hunt 1999). We used mark-recapture methods to directly determine various factors affecting dispersal. Results of $2 \mathrm{yr}$ of experiments $(1996,1997)$ suggested that $O$. nubilalis are less likely to disperse out of some cornfields than previously thought. Because irrigated cornfields could provide a favorable adult habitat, we suspected adults were remaining in many eastern Nebraska cornfields. Marked adults had been observed in cornfields near their release sites. Therefore, in 1998 we conducted experiments to directly examine local dispersal and mating behavior of adults in and proximal to irrigated and non-irrigated corn. These data are then compared

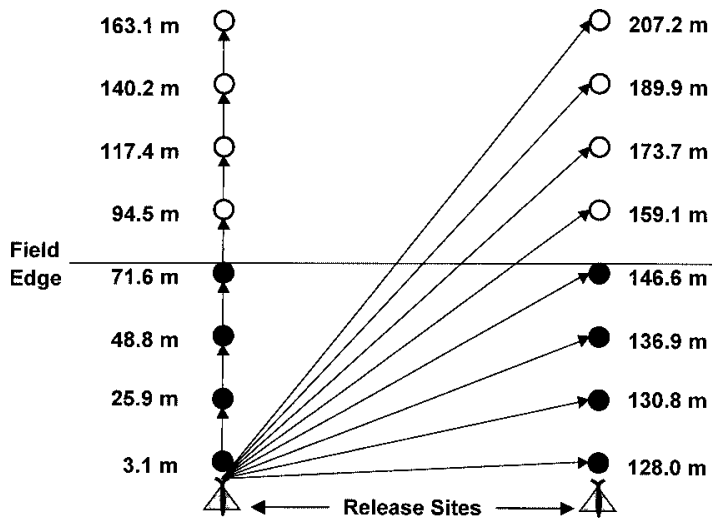

Fig. 1. Light trap configuration in and around European corn borer release field. Open circles indicate traps outside of the cornfield and solid circles indicate traps within the cornfield.

with the current model of $O$. nubilalis dispersal in Iowa.

\section{Materials and Methods}

Mark-Release-Recapture Study. Research was conducted at the University of Nebraska Research and Development Center, Ithaca, NE. Marked O. nubilalis were supplied from colonies established by the USDA-ARS Corn Insects and Crop Genetics Research Unit, Ames, IA. The Iowa colonies are reestablished yearly from feral adults collected each summer. Adults were marked by rearing them on standard diets (Lewis and Lynch 1969) containing oil-soluble dyes [Sudan Blue 670 (C.I. 61554) and Sudan Red 7B (C.I. 26050), Aldrich, Milwaukee, WI]. Dyes were tested to ensure they did not appreciably alter O. nubilalis biology (Hunt et al. 2000).

Field and Trapping Site Locations. Two cornfields were selected with field centers $\approx 3.2 \mathrm{~km}$ apart (north to south). Both fields were rectangular and $\approx 9 \mathrm{ha}$. The northern field was furrow irrigated and planted at $\approx 74,000$ plants per hectare. The southern field was non-irrigated and planted at $\approx 57,000$ plants per hectare. Cultural practices standard for maximum production in eastern Nebraska were used in both fields. Both fields were relatively free of weeds.

Two release sites were established $128 \mathrm{~m}$ apart in each field (Fig. 1). Eight light traps (12 W, $12 \mathrm{~V}$, Universal Black Light Traps, BioQuip Products, Gardena, CA) were placed in a transect extending from each release site (16 traps per field). The first trap in a transect was positioned $3.1 \mathrm{~m}$ from the release site, and subsequent traps were placed at 22.9-m intervals. Four traps were in the field, and four traps were outside the field in grassy areas primarily composed of smooth bromegrass (Bromus inermis Leyss).

Marked Adult Release. Two releases were made corresponding to the two flights of $O$. nubilalis that occur in eastern Nebraska. Each release occurred after the peak of the corresponding native adult flight (mid- 
Table 1. Mark-recapture study release dates, field phenologies, release numbers, and recapture numbers for $O$. nubilalis

\begin{tabular}{|c|c|c|c|c|c|c|}
\hline \multirow{2}{*}{$\begin{array}{l}\text { Release } \\
\text { date }\end{array}$} & \multirow{2}{*}{$\begin{array}{c}\text { Field } \\
\text { phenology }\end{array}$} & \multirow{2}{*}{ Field type } & \multirow{2}{*}{$\begin{array}{l}\text { Approx. no. } \\
\text { released }\end{array}$} & \multicolumn{3}{|c|}{ No. recaptured } \\
\hline & & & & 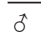 & Mated 우 & Virgin 우 \\
\hline \multirow[t]{2}{*}{20 June } & V9-V10 & Irrigated & 3,358 & 13 & 10 & 0 \\
\hline & V9-V10 & Non-irrigated & 3,358 & 7 & 2 & 1 \\
\hline \multirow[t]{2}{*}{9 August } & $\mathrm{R} 2-\mathrm{R} 3$ & Irrigated & 7,220 & 30 & 22 & 8 \\
\hline & R2-R3 & Non-irrigated & 7,220 & 7 & 2 & 1 \\
\hline
\end{tabular}

June and early August), as determined by light-trap catches of feral adults. For each release, pupation rings (waxed, corrugated cardboard rings) containing marked pupae were placed at the release sites and adults were allowed to emerge. In each field, red pupae were placed at one site and blue at the other. Pupation rings were left at the release sites for $48 \mathrm{~h}$ and then removed.

Trapping began $24 \mathrm{~h}$ after the removal of the pupation rings, thereby allowing adults from 24 to $72 \mathrm{~h}$ to disperse before being trapped. Trap contents were collected daily for $3 \mathrm{~d}$. Number, sex, female mating status, and internal color of $O$. nubilalis were recorded. Female mating status was recorded as mated or unmated and determined by examining females for the presence of a spermatophore. Corn phenology also was recorded.

Release-Recapture Study. The release sites for the mark-release-recapture were positioned within the cornfields, and adults had to disperse $72 \mathrm{~m}$ before encountering the grassy habitat (smooth bromegrass) at and beyond the field edge. Initial examination of the data suggested $O$. nubilalis remained in the irrigated cornfield. To more directly examine habitat selection, we conducted a release-recapture study where released adults had an immediate choice of habitats (irrigated corn or a grassy field edge [smooth bromegrass mixed with broadleaf weeds]). Because the released adults were unmarked, we used nearby traps to monitor background $O$. nubilalis population levels. Adults were released when natural adult populations were low.

On 23 August an unmarked O. nubilalis releaserecapture study was conducted along an edge of an irrigated cornfield. The experimental design was a randomized complete block with three replications. Each replication consisted of a release site in the second row from the field edge, a pair of light traps bracketing the release site (one in and one outside of the field), and a pair of light traps similarly positioned $45 \mathrm{~m}$ away but without a release site. The paired traps were positioned equidistant $(4.6 \mathrm{~m})$ from the release site and opposite one another. One trap was within the cornfield at ear height $(\approx 1 \mathrm{~m})$, and the other outside the corn at the top of the smooth bromegrass and broadleaf weed canopy (approximately the same height as the within field trap). The pair positioned similarly but $45 \mathrm{~m}$ away (control traps) was used to monitor background $O$. nubilalis population levels away from the release sites. The within field traps were almost completely obscured by the corn canopy. Corn phenology was R4-R5 (Ritchie et al. 1993).

Four pupation rings were placed at ear height at the release sites. Release and concurrent trapping contin- ued for $5 \mathrm{~d}$. The number, sex, and female mating status of $O$. nubilalis were recorded for each trapping date.

Mating Study. Because moisture is critical to $O$. nubilalis physiological processes and mating success, we designed a mating study to examine whether there was a difference in mating success between what has been documented as a favorable mating site foxtail (Setaria spp), and corn. On 20 August, five mating cages were established in dense foxtail and five cages in corn. The mating cages in the foxtail consisted of a bubble of bridal veil pegged to the ground at the bottom and cinched at the top to a 1-m-high wooden stake. Within cage volume was $\approx 0.50 \mathrm{~m}^{3}$. Access was through a Velcro seam. The mating cages in corn consisted of a similar bubble of bridal veil cinched around an R3 corn plant above and below the ear.

At $\approx 0700$ hours (CDT) on 20 and 21 August, newly emerged adult male and female $O$. nubilalis adults were collected from emergence cages and held in paper bags. Each bag held six males or five females. The bags were sprayed on the inside with water. At $\approx 1830$ hours each evening, six males and five unmated females were placed in each mating cage. At $\approx 0730$ hours on the morning after caging, mating status of the females was recorded.

Statistical Analysis. In the mark-release-recapture study, analysis of variance (ANOVA) procedures were used to determine main effects (SAS Institute 1990). The number of adults released per field differed between the release dates (Table 1 ). This initially presented a problem when examining the effect of release date on the number of adults recaptured. Because we are comparing means of numbers of adults recaptured, significant differences attributed to release date could be a result of the initial numbers of adults released. Therefore, to remove the effect of initial release number, we adjusted the recapture numbers based on a release of 5,289 adults per field (average of the June and August releases). Similarly, when examining the number of males and females recaptured the recapture numbers were adjusted based on a release of 2,996 males per field and 2,294 females per field (averages of the June and August releases).

A significant difference between effects of the distance variables (trap location, trap proximity, and distance) could confound one another, so type I sum of squares (sequential sum of squares) significance levels are presented. Type I sum of squares allows effects to be evaluated sequentially and removed from the model.

In the release-recapture and mating studies, ANOVA procedures were used to determine main 


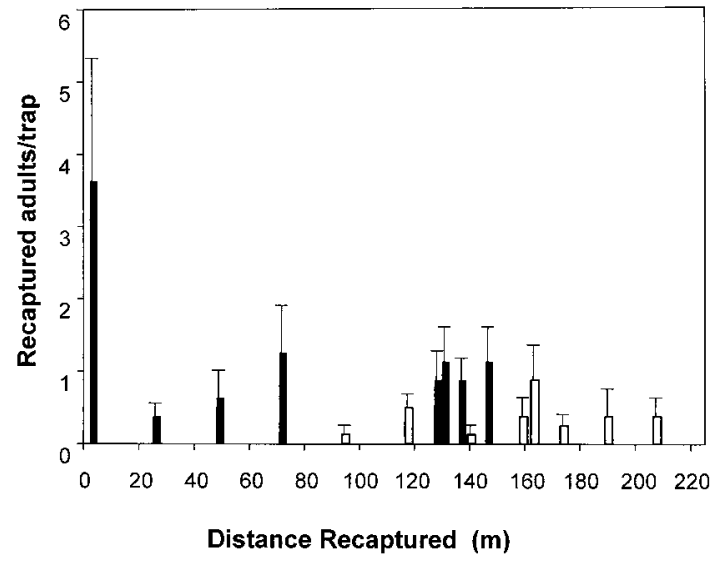

Fig. 2. Overall mean $\pm \mathrm{SE}$ recaptured European corn borers (adults/trap). Solid bars are within field traps and open bars are outside field traps.

effects and means were separated with LSMEANS procedures (SAS Institute 1990). Some spider predation occurred in about half of the cages in the mating study, so remaining live female counts were included in the analysis as a covariate to mated females.

\section{Results and Discussion}

Mark-Release-Recapture Study. The overall mean number of recaptured $O$. nubilalis adults per trap by distance from release site is presented in Fig. 2. Trap location indicates traps located within versus outside of the cornfield. Half of the traps were within and half were outside of the cornfield. Note the within-field adults per trap at $128 \mathrm{~m}$ to $147 \mathrm{~m}$ (Fig. 2); these adults were recaptured within the field but in the trap transect opposite their release site (Fig. 1). Trap proximity indicates moths per trap immediately proximal $(3.1 \mathrm{~m})$ versus away $(\geq 25.9 \mathrm{~m})$ from the release site (note the relatively high number of adults per trap at $\approx 3.1 \mathrm{~m}$ ).

According to the Iowa model of $O$. nubilalis dispersal, males and unmated females should leave the field shortly after emergence (fields were free of weeds) and settle outside of the field in action sites. Males are expected to disperse further in search of mates. After mating in the action sites, the females should move back and forth between corn and action sites, ovipositing in the corn and resting or imbibing water in the action sites. Under these assumptions, we expected unmated females would be recaptured outside of the corn in the grassy areas (smooth bromegrass), with more recaptured near the field than away from the field during the June release (in Iowa, smooth bromegrass is an effective spring action site, but less effective later in the summer). We expected males would be recaptured outside of the corn, probably in the same areas as the unmated females, because they would be searching for mates. Male movement could be somewhat confounded by pheromone-emitting females from the native population, although we released after the peak of the native flights. Mated females should be recaptured within and outside of the corn, with possibly more recaptured near the edge of the corn. Recaptures in and near the irrigated corn

Table 2. ANOVA for recaptured $O$. nubilalis per trap (adults/trap, dependent variable)

\begin{tabular}{|c|c|c|c|c|}
\hline Group & Source $^{a}$ & $F$ & $\begin{array}{c}\text { Unadjusted } \\
\text { adults/trap, } \\
\quad P>F\end{array}$ & $\begin{array}{c}\text { Adjusted }^{b} \\
\text { adults/trap, } \\
P>F\end{array}$ \\
\hline \multirow[t]{7}{*}{ Overall } & Release date & $<0.009$ & & 0.9660 \\
\hline & Field type & 13.50 & & 0.0004 \\
\hline & Release date $*$ field type & 1.08 & & 0.3003 \\
\hline & Trap location & 16.44 & & 0.0001 \\
\hline & Trap proximity & 28.12 & & 0.0001 \\
\hline & Distance & 1.38 & & 0.2425 \\
\hline & Distance $*$ distance & 0.95 & & 0.3328 \\
\hline \multirow[t]{4}{*}{ Nonirrigated June release } & Trap location & 6.99 & 0.0135 & \\
\hline & Trap proximity & 1.53 & 0.2269 & \\
\hline & Distance & 2.13 & 0.1559 & \\
\hline & Distance $*$ distance & 0.36 & 0.5531 & \\
\hline \multirow[t]{4}{*}{ Nonirrigated August release } & Trap location & 6.11 & 0.0200 & \\
\hline & Trap proximity & 0.03 & 0.8700 & \\
\hline & Distance & 0.06 & 0.8102 & \\
\hline & Distance $*$ distance & 0.05 & 0.8261 & \\
\hline \multirow[t]{4}{*}{ Irrigated June release } & Trap location & 7.83 & 0.0094 & \\
\hline & Trap proximity & 11.46 & 0.0022 & \\
\hline & Distance & 0.32 & 0.5786 & \\
\hline & Distance $*$ distance & 0.92 & 0.3458 & \\
\hline \multirow[t]{4}{*}{ Irrigated August release } & Trap location & 3.43 & 0.0749 & \\
\hline & Trap proximity & 26.53 & 0.0001 & \\
\hline & Distance & 0.55 & 0.4647 & \\
\hline & Distance $*$ distance & 0.03 & 0.8539 & \\
\hline
\end{tabular}

\footnotetext{
${ }^{a}$ Release date, 20 June or 9 August; field type, irrigated or nonirrigated; trap location, within or outside of the cornfield; trap proximity, directly proximal $(3.1 \mathrm{~m})$ or away from $(\geq 25.9 \mathrm{~m})$ the release site; distance, distance away from the release site. For the overall group, $\mathrm{df}=1,120$; for each irrigation, release date group $\mathrm{df}=1,27$.

${ }^{b}$ Number of adults recaptured adjusted to a common release number of 5,289 adults.
} 
June Release, Non-Irrigated

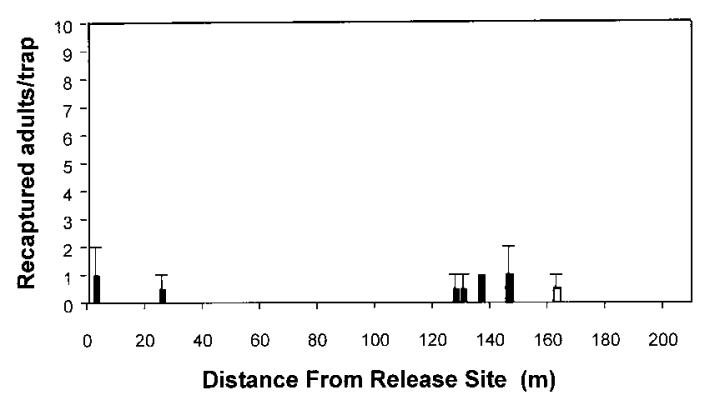

June Release, Irrigated

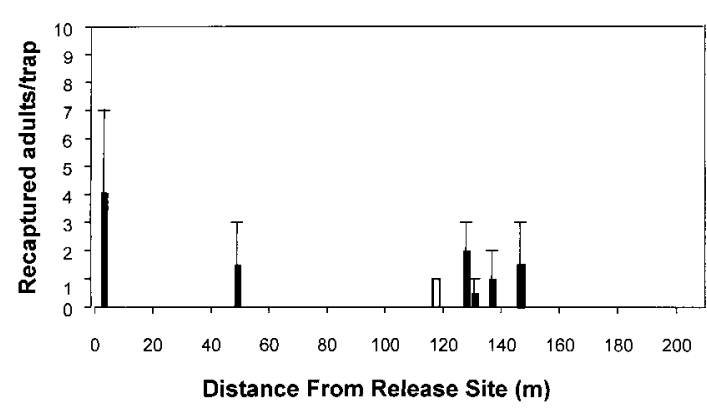

August Release, Non-Irrigated

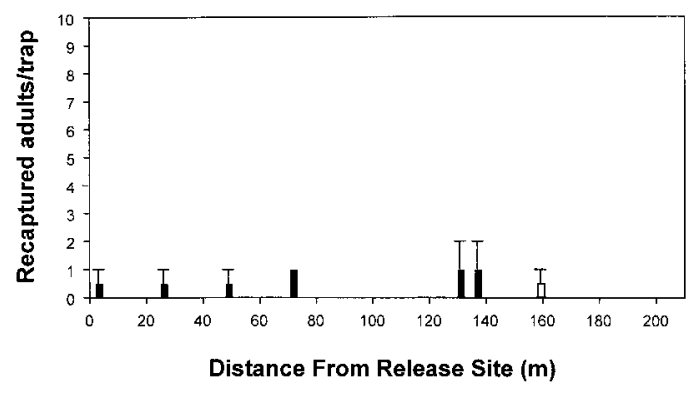

August Release, Irrigated

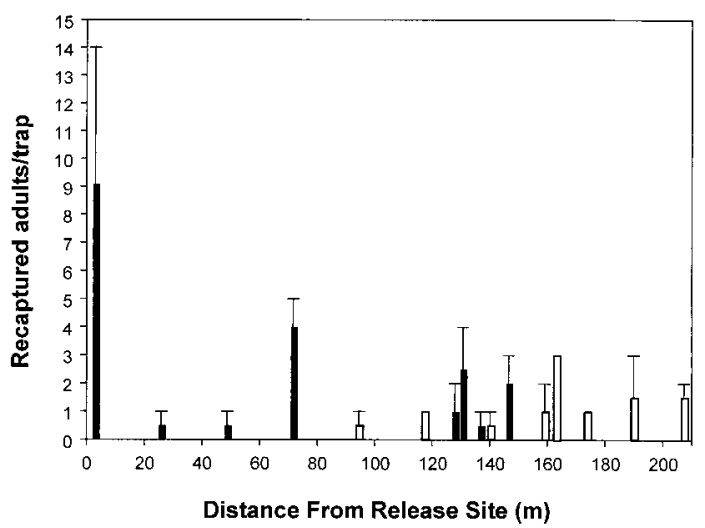

Fig. 3. Mean \pm SE recaptured European corn borers (adults/trap) by release date and field type. Solid bars are within field traps and open bars are outside field traps.

would be higher than in and near non-irrigated corn because the irrigated corn provided more favorable oviposition sites, due to its high humidity and high plant density. Although some of our results were consistant with the expectations from the Iowa model of O. nubilalis dispersal, others were not.

The effects of field type, trap location, trap proximity, and release date $*$ field type $*$ trap proximity were highly significant (Table 2 ). There were significantly more adults per trap in and proximal to irrigated than non-irrigated cornfields, significantly more adults per trap within than outside of the corn, and significantly more adults per trap directly proximal the release site than away from the release site.

Further analysis by release date and field type supports the above results. The primary factors affecting dispersal were trap location and trap proximity (Table 2 ). The mean number of adults per trap by distance from release site for each release date and field type combination is presented in Fig. 3. Analysis by release date and field type allows use of unadjusted counts because the analysis is not confounded by the different numbers of adults released on the different dates. The difference between irrigated and non-irrigated cornfields became evident. In the irrigated field there was a significant effect of trap proximity for both release dates (Table 2), but there was no significant effect of trap proximity in the non-irrigated field. There were significantly more adults recaptured directly proximal to the release site $(3.1 \mathrm{~m})$ than away $(\geq 25.9 \mathrm{~m}$ ) in irrigated fields (Fig. 3). This finding is contrary to what would be expected if the adults left the field shortly after emergence, as suggested from previous reports of $O$. nubilalis dispersal (e.g., Showers et al. 1980). The released adults had 24 to $72 \mathrm{~h}$ to move before trapping commenced. Even if the adults left the field and subsequently returned, as could occur with ovipositing females, we would not expect them to return to their site of emergence. Adults released in the non-irrigated field dispersed more readily than in the irrigated field. The tendency for adults to disperse more widely from the non-irrigated field than the irrigated field is further illustrated by the significant effect of field type as observed in the overall number of adults per trap analysis (Table 2 ). Fewer moths were recaptured in and around the non-irrigated field than the irrigated field. Adults released in the non-irrigated field not only dispersed away from their release site but also left the vicinity of the field. It is generally thought that when adult $O$. nubilalis 
Table 3. ANOVA for recaptured $O$. nubilalis per trap (adults/trap, dependent variable) by sex and field type

\begin{tabular}{|c|c|c|c|}
\hline Group & Source $^{a}$ & F & $\begin{array}{c}\text { Adjusted }^{b} \\
\text { adults/trap, } \\
P>F\end{array}$ \\
\hline $\begin{array}{l}\text { Male } \\
\quad \text { Nonirrigated }\end{array}$ & $\begin{array}{l}\text { Release date } \\
\text { Trap location } \\
\text { Trap proximity } \\
\text { Distance } \\
\text { Distance } * \text { distance }\end{array}$ & $\begin{array}{l}0.06 \\
7.51 \\
2.76 \\
2.46 \\
1.30\end{array}$ & $\begin{array}{l}0.4430 \\
0.0081 \\
0.1019 \\
0.1224 \\
0.2492\end{array}$ \\
\hline $\begin{array}{l}\text { Mated female } \\
\text { Nonirrigated }\end{array}$ & $\begin{array}{l}\text { Release date } \\
\text { Trap location } \\
\text { Trap proximity } \\
\text { Distance } \\
\text { Distance } * \text { distance }\end{array}$ & $\begin{array}{l}0.93 \\
1.90 \\
0.71 \\
1.01 \\
0.29\end{array}$ & $\begin{array}{l}0.3380 \\
0.1739 \\
0.4013 \\
0.3186 \\
0.5932\end{array}$ \\
\hline Male Irrigated & $\begin{array}{l}\text { Release date } \\
\text { Trap location } \\
\text { Trap proximity } \\
\text { Distance } \\
\text { Distance } * \text { distance }\end{array}$ & $\begin{array}{r}0.65 \\
6.89 \\
10.59 \\
0.37 \\
0.04\end{array}$ & $\begin{array}{l}0.4220 \\
0.0110 \\
0.0019 \\
0.5456 \\
0.8458\end{array}$ \\
\hline $\begin{array}{l}\text { Mated female } \\
\text { Irrigated }\end{array}$ & $\begin{array}{l}\text { Release date } \\
\text { Trap location } \\
\text { Trap proximity } \\
\text { Distance } \\
\text { Distance } * \text { distance }\end{array}$ & $\begin{array}{r}0.86 \\
6.12 \\
10.21 \\
1.24 \\
1.79\end{array}$ & $\begin{array}{l}0.3583 \\
0.0163 \\
0.0023 \\
0.2697 \\
0.1859\end{array}$ \\
\hline
\end{tabular}

${ }^{a}$ Release date, 20 June or 9 August; trap location, within or outside of the cornfield; trap proximity, directly proximal (3.1 m) or away from $(\geq 25.9 \mathrm{~m})$ the release site; distance, distance away from the release site. For each sex, irrigation group, $\mathrm{df}=1,58$.

${ }^{b}$ Number of adults recaptured adjusted to a common release number of 2,995 for males and 2,294 for mated females.

leave a cornfield, most settle in locations of suitable microclimate as they encounter them (e.g., Showers et al. 1980). If so, we would have observed a significant number of adults recaptured in the traps outside of the field in the dense smooth bromegrass during the June release. Instead, very few adults were recaptured outside of non-irrigated fields (Fig. 3). It appeared that once they started dispersing from an unfavorable habitat, non-irrigated corn, the tendency was for them to continue to disperse. Increased dispersal away from unfavorable habitat also was observed during 1996 and 1997 mark-release-recapture studies (Hunt 1999), where mean recapture distances of $O$. nubilalis released in unattractive (with respect to oviposition) cornfields were greater than those released from attractive cornfields.

The effect of trap location was significant for both release dates at the non-irrigated field and for the June release at the irrigated field (Table 2). There were significantly more adults per trap within both fields compared with outside the fields. The effect of trap location neared significance at the irrigated field for the August release date, although we suggest that the true effect of the within-field traps may have been obscured for this release. During August the corn canopy was fully developed and corn plants were well within $1 \mathrm{~m}$ of the traps, partially obscuring them. Even so, there were more adults per trap within the field than outside the field. Adult $O$. nubilalis exhibited a tendency to remain in the cornfield, particularly in the irrigated field where the humidity would be relatively high and light penetration was probably reduced. If the higher adult recapture rate was because females returned to the field to oviposit, we would expect to observe an edge effect, but that was not evident.
Movement and behavior differ between males, mated females, and unmated females (Showers et al. 1976, Sappington and Showers 1983). Unmated female O. nubilalis require moisture and mating sites, males must find females and respond to pheromones, and mated females require oviposition sites. Therefore, initial dispersal may differ. Recapture of unmated females was too low for separate analysis, although some trends were apparent. These females had at least $24 \mathrm{~h}$ to move away from the release site and out of the irrigated field. Eighty percent (eight females) were recaptured in and around the irrigated cornfield. Of these, $75 \%$ were recaptured at the trap closest to their release site $(3.1 \mathrm{~m})$. At the non-irrigated field, the two unmated females were recaptured within the field, $25.9 \mathrm{~m}$ and $71.6 \mathrm{~m}$ from their release site, respectively. If the unmated females moved out of the fields to mate, we would have expected to recapture them outside of the field in the dense smooth bromegrass (in June).

Males and mated females per trap were analyzed by field type. Results are presented in Table 3. At the non-irrigated field, a significant effect was indicated for trap location for males. More males than females were recaptured in within-field traps. Significant effects were indicated for trap location and trap proximity for both males and mated females at the irrigated field. There were more males and mated females per trap within than outside the field, and there were significantly more males and mated females per trap directly proximal to their release site. This finding further supports the premise that the mated females were not simply returning to the field to oviposit, but rather mated in the cornfield and remained near their release site. The males may have remained in the field or may be responding to the unmated females emitting 
sex pheromones in the cornfield. There were no significant effects indicated for mated females at the non-irrigated field for any factor.

Dispersal patterns of insects released from a point source often exhibit a direct relationship to distance and fit some model of decay, such as a negative exponential (Plant and Cunningham 1991). The absence of a significant effect associated with distance or distance $*$ distance for adults per trap at both the irrigated and non-irrigated cornfields (Table 2) indicate the importance of the local environment to $O$. nubilalis dispersal. In the irrigated field, one might expect there to be a direct relationship between adults per trap and distance from the release site, with the number of adults per trap diminishing as distance increases. Likewise, in the non-irrigated field one might expect a similar pattern to emerge outside the corn, particularly during the June release. However, this was not the case. In the irrigated field, a significant number of adults remained near their release site (Fig. 3). For those that dispersed, they tended to remain in the corn. Even in the non-irrigated field, where adults tended to leave the field and local vicinity of the field, more males (of adults that remained) were recaptured in the field than outside the field. This finding supports the premise that the local environment of the adult emergence site (for non-irrigated corn, possibly shading) is what primarily affects local $O$. nubilalis dispersal.

Release-Recapture Study. In this study we examined whether male and unmated female $O$. nubilalis exhibited a habitat preference when presented a choice between a mixed smooth bromegrass and broadleaf-weed field edge or an irrigated cornfield. If the adults had an immediate preference for the grassand-weed field edge, we would expect to recapture more adults in traps located in the field edge than in the cornfield.

Daily means for males and unmated females per trap are presented in Fig. 4. The number of adults recaptured was always higher at the release sites than at the non-release sites. Few adults were recaptured at the non-release sites. The slightly higher recapture rate of males than females at the non-release sites may be because males disperse further than females (Hunt 1999). To compare recaptures of released adults, the number of adults per trap at a non-release site was subtracted from the number of adults per trap at its respective release site trap. The difference represented the number of released adults recaptured (adults per trap), and these differences were compared between the field edge and corn for males and unmated females. There were no significant differences across days between mean $\pm \mathrm{SE}$ number of adults per trap in the field edge and mean number of adults per trap in corn for males $(F=0.01 ; \mathrm{df}=1,2 ; P=$ $0.95)$ or unmated females $(F=0.25 ; \mathrm{df}=1,2 ; P=0.67)$. The mean numbers of males across days were $7.93 \pm 1.91$ in the field edge and $7.68 \pm 2.03$ in the corn. The mean numbers of unmated females across days were $8.67 \pm$ 1.38 in the field edge and $6.78 \pm 1.46$ in the corn.
Because the within-field light traps were obscured by the corn plants, there are two possible explanations for our results. If the effective attraction radius is relatively small (1-3 m) as demonstrated by Baker and Sadovy (1978) for other moth species, dispersal of males and unmated females was random or slightly favoring corn (corn plants were within $1 \mathrm{~m}$ of the trap, partially obscuring it at this distance). If the effective attraction radius was larger $(>3 \mathrm{~m})$, dispersal of the released males and unmated females heavily favored corn. We suggest the effective attraction radius of our traps is relatively small (we used small, low-wattage bulbs placed relatively low in the corn canopy), and a random dispersal, or one favoring corn, is occurring. After day 1 or 2 , the male recapture was probably not independent from the unmated female recapture because they would be responding to pheromone release by the unmated females. Regardless, male and unmated female $O$. nubilalis did not display an initial tendency to disperse out of irrigated corn and into the mixed smooth bromegrass and broadleaf-weed field edge.

Mating Study. There was no significant effect of location (foxtail or corn) for the number of mated females $(F=0.01 ; \mathrm{df}=1,8 ; P=0.91)$. The mean \pm $\mathrm{SE}$ number of mated females was $2.12 \pm 0.40$ $(42.4 \%$ mated) in foxtail, and $2.10 \pm 0.43(42.0 \%$ mated) in corn. The results presented in the markrelease-recapture study indicate that $O$. nubilalis can mate successfully in irrigated cornfields. Although cages prevented adult dispersal, the lack of significant differences between mating frequency in foxtail and corn indicate that mating is potentially as efficient in irrigated corn as in foxtail.

In conclusion, the results of our $O$. nubilalis dispersal and behavior studies differ from the prevailing model of O. nubilalis dispersal (Showers et al. 1980). We did not always observe premating dispersal of adults out of weed-free cornfields, nor did we see a significant movement by distance relationship. Although the scale in these experiments was small and the range of habitats limited, our studies demonstrated that the current model is not the only description of O. nubilalis local dispersal.

The field environment and microclimate are very different in June than in August and between irrigated and non-irrigated cornfields. During June the corn is relatively short, in vegetative stages, and exposed to light and air movement. In August the corn is tall, in reproductive stages, and the fully developed canopy is more protective, reducing light penetration and air movement. Irrigated fields usually have a higher plant density, receive more moisture, and are more lush than non-irrigated fields. Moisture parameters (e.g., relative humidity) that have been positively correlated with adult $O$. nubilalis population density (DeRozari et al. 1977) and physiological processes (Vance 1949, Kira et al. 1969, Webster and Cardé 1982, Royer and McNeil 1991) would vary with release date and field type.

After adjusting for adult release rates, we did not observe a difference in $O$. nubilalis dispersal behavior between release dates. We observed a tendency for 


\section{Males}

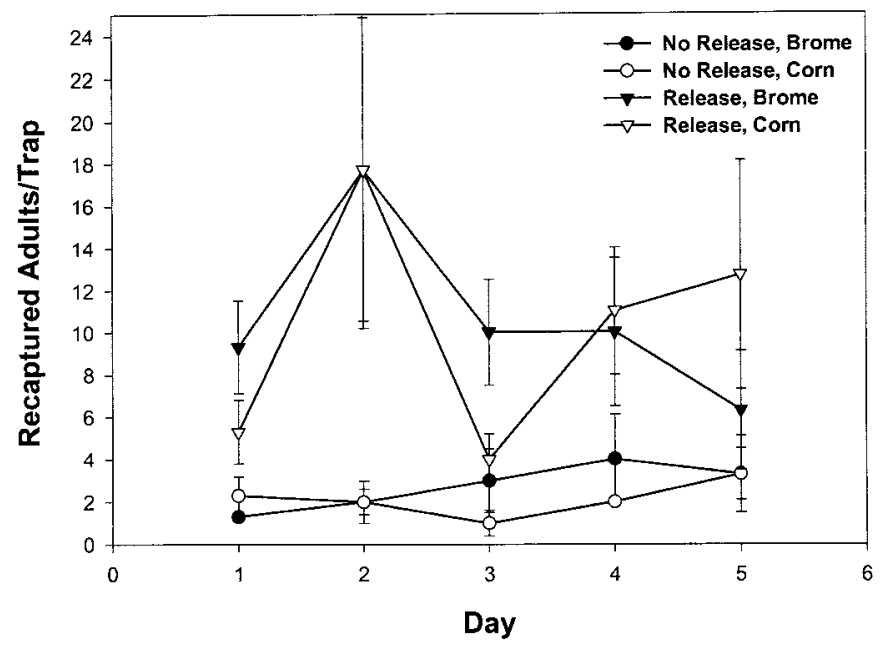

Unmated Females

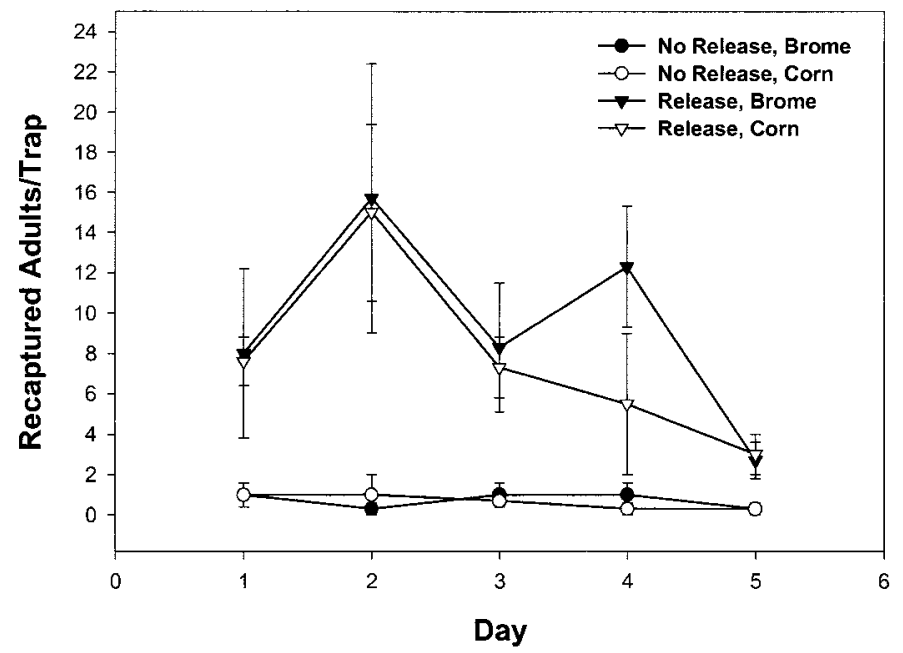

Fig. 4. Mean $\pm \mathrm{SE}$ recaptured European corn borers (adults/trap) within and outside of a cornfield after adult release from the field edge.

limited dispersal in and away from corn that was moderated by field type. Irrigated, high-plant-density fields held adults. Adults from non-irrigated, lowerplant-density fields generally left the field and fieldvicinity, although even in non-irrigated corn some adults display a tendency to remain in corn, given a favorable plant stage (the corn was at stage V9-V10 in June in our study). We would expect adults emerging in earlier-stage corn, or corn stubble in soybean [ Glycine $\max (\mathrm{L}$.) Merill] field, to exhibit a greater tendency to disperse from the field and immediate area.

Because of research that identifies moisture parameters to be positively correlated to $O$. nubilalis fitness and behavior (Vance 1949, DeRozari et al. 1977, Royer and McNeil 1991), we agree with Showers et al. (1980) that microclimate is the primary factor determining O. nubilalis local dispersal in corn. Adults readily dispersed into an irrigated cornfield when released at a field edge. Also, mating was observed to be efficient in irrigated corn. Thus, we suggest the more humid and shaded microclimate of the irrigated cornfield explains most of the differences between what we observed between our results and the Iowa model of O. nubilalis dispersal. However, there also are differences between our observed $O$. nubilalis dispersal in and around non-irrigated corn and predictions of the Iowa model. The Iowa model predicts that adults leaving the non-irrigated field should settle in habitats of 
favorable microclimate as they encounter them. If so, we should have observed more adults per trap in the traps in the smooth bromegrass areas outside of the field (both irrigated and non-irrigated) during the June release, but we did not. This discrepancy may be explained in part because most of the previous studies did not use marked adults, so the field of adult origin was unknown. Other environmental, geographic, or agronomic factors also may be a source of differences between studies.

Field type mediated dispersal of $O$. nubilalis and this finding has important implications for resistance management. Our results indicate there is not a single, appropriate set of dispersal parameters that can be incorporated into management models. In an irrigated field of high plant density, O. nubilalis adults emerge within the cornfield and may mate without dispersing away from the field. Those that do leave may become mated before they leave or stay close to the field. In this case non-random mating is high and movement of susceptible adults to the target Bt cornfield would be limited. Even in a non-irrigated field, where there was significant movement of adults out and away from corn, we recaptured more adults per trap within the field, including unmated females, so there is probably a degree of non-random mating in non-irrigated fields. This dispersal continuum must be considered for resistance management.

We have identified some of the factors affecting O. nubilalis local dispersal in corn, but the final form that the dispersal pattern will take depends on a variety of region-specific variables such as action site availability, host availability, agronomic practices, climate, and their interaction with O. nubilalis life history.

\section{Acknowledgments}

We thank Blair Siegfried and Robert Wright (Univ. of Nebraska) for initial reviews of this manuscript. This research was supported in part by the North Central Regional Research Project NC-205, DeKalb Genetics, Monsanto Company, Mycogen Plant Sciences Corporation, and Novartis Seeds. This is Journal Series No. 12768 of the Nebraska Agricultural Research Division and Contribution No. 1042 of the Department of Entomology, University of Nebraska-Lincoln.

\section{References Cited}

Baker, R. R., and Y. Sadovy. 1978. The distance and nature of light-trap response of moths. Nature (Lond) 276: 818-821.

Caprio, M. A. 1998. Evaluating resistance management strategies for multiple toxins in the presence of external refuges. J. Econ. Entomol. 91: 1021-1031.

DeRozari, M. B., W. B. Showers, and R. H. Shaw. 1977. Environment and the sexual activity of the European corn borer. Environ. Entomol. 6: 657-665.

Derrick, M. E., and W. B. Showers. 1990. Relationship of adult European corn borer (Lepidoptera: Pyralidae) in action sites with egg masses in the cornfield. Environ. Entomol. 19: 1081-1085.

Hunt, T. E. 1999. Dispersal and behavior of adult European corn borer in and around corn. Ph.D. dissertation, University of Nebraska, Lincoln, NE.
Hunt, T. E., R. L. Hellmich, J. M. Dyer, L. G. Higley, and J. F. Witkowski. 2000. Oil-soluble dyes for marking European corn borer (Lepidoptera:Crambidae). J. Entomol. Sci. 35: 338-341.

Kira, M. T., W. D. Guthrie, and J. L. Huggans. 1969. Effect of drinking water on production of eggs by the European corn borer. J. Econ. Entomol. 62: 1366-1368.

Koziel, M. G., G. L. Beland, C. Bowman, N. B. Carozzi, R. Crenshaw, L. Crossland, J. Dawson, N. Desai, M. Hill, S. Kadwell, K. Launis, K. Lewis, D. Maddox, K. McPherson, M. R. Meghji, E. Merlin, R. Rhodes, G. W. Warren, M. Wright, and S. V. Evola. 1993. Field performance of elite transgenic maize plants expressing an insecticidal protein derived from Bacillus thuringiensis. BioTechnology 11: 194 200.

Lee, D. A. 1988. Moth density and oviposition patterns of the European corn borer, Ostrinia nubilalis (Lepidoptera: Pyralidae), in Alberta. Environ. Entomol. 17: 220-224.

Lewis, L. C., and R. E. Lynch. 1969. Rearing the European corn borer on diets containing corn leaf and wheat germ. Iowa State J. Sci. 44: 9-14.

Plant, R. E., and R. T. Cunningham. 1991. Analyses of the dispersal of sterile Mediterranean fruit flies (Diptera: Tephritidae) from released from a point source. Environ. Entomol. 20: 1493-1503.

Ritchie, S. W., J. J. Hanway, and G. O. Benson. 1993. How a corn plant develops. Special Report 48: Iowa State University Cooperative Extension Service, Ames, IA.

Royer, L., and J. N. McNeil. 1991. Changes in calling behavior and mating success in the European corn borer (Ostrinia nubilalis), caused by relative humidity. Entomol. Exp. Appl. 61: 131-138.

Sappington, T. W., and W. B. Showers. 1983. Adult European corn borer (Lepidoptera: Pyralidae) flight activity in and away from aggregation sites. Environ. Entomol. 12: $1154-1158$.

SAS Institute. 1990. User's manual, version 6. SAS Institute, Cary, NC.

Showers, W. B., G. L. Reed, and H. Oloumi-Sadeghi. 1974. European corn borer: attraction of males to synthetic lure and to females of different strains. Environ. Entomol. 3: $51-58$.

Showers, W. B., G. L. Reed, J. F. Robinson, and M. B. DeRozari. 1976. Flight and sexual activity of the European corn borer. Environ. Entomol. 5: 1099-1104.

Showers, W. B., E. C. Berry, and L. Von Kaster. 1980. Management of 2nd-generation European corn borer by controlling moths outside the cornfield. J. Econ. Entomol. 73: $88-91$.

Sparks, A. N. 1963. Preliminary studies of factors influencing mating of the European corn borer. Proc. N. Cent. Br. Entomol. Soc. Am. 18: 95.

Tabashnik, B. E., and B. A. Croft. 1982. Managing pesticide resistance in crop-arthropod complexes: interactions between biological and operational factors. Environ. Entomol. 11: 1137-1144.

Vance, A. M. 1949. Some physiological relationships of the female European corn borer moth in controlled environments. J. Econ. Entomol. 42: 474-484.

Webster, R. P., and R. T. Cardé. 1982 . Influence of relative humidity on calling behavior of the female European corn borer moth (Ostrinia nubilalis). Entomol. Exp. Appl. 32: 181-185. 